Досліджені основні закономірності процесів видобутку буритину на денну поверхню з піщаних буритиноносних родовищ, гідромеханічним способом із застосуванням інтенсифікаторів та запропонована нова технологія з вибором раціональних параметрів видобутку. Встановлені закономірності впливу води і повітря на розрідження піманих середовищ, які залежать від інтенсивності подачі в бурштиноносний масив газорідинної суміші

Ключові слова: бурштин, зрідження, сегрегація, гідромеханічний спосіб, віброгідравлічний інтенсифікатор, вібровипромінювач

Исследованы основные закономерности процессов добычи янтаря на дневную поверхность из песчаных янтареносных месторождений гидромеханическим способом с использованием интенсификаторов и предложены новые технологии с выбором рациональных параметров добычи. Установлены закономерности влияния воды и воздуха на разжижение песчаных сред, которые зависят от интенсивности подачи в янтареносный массив газожидкостной смеси

Ключевые слова: янтарь, ожижение, сегрегачия, гидромеханический способ, виброгидравлический интенсификатор, виброизлучатль

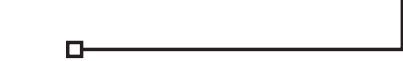

UDC 622.232.5:622.2

DOI: $10.15587 / 1729-4061.2016 .72404$

\section{RESULTS OF EXPERIMENTAL STUDIES OF AMBER EXTRACTION BY HYDROMECHANICAL METHOD IN UKRAINE}

Z. Malanchuk

Doctor of Technical Science, Professor* E-mail: malanchykzr@ukr.net

V. Korniyen ko $\mathrm{PhD}$, Associate Professor*

E-mail: kvja@mail.ru

Ye. Malanchuk

Doctor of Technical Science, Associate Professor** E-mail: malanchykez@mail.ru

A. K h ryst y u k

Postgraduate Student**

E-mail: hristuk_orcid@ukr.net *Department of Development of Deposits and Mining*** **Department of Automation, Electrical Engineering and Computer-integrated Technologies*** $* * *$ National University of Water Management and Nature Resources use Sobornaya str., 11, Rivne, Ukraine, 33028

\section{Introduction}

Amber in various countries has its own distinguishing features that set it apart in different parts of the world [1]. Canadian researchers conducted the analysis of amber from 11 amber-containing fields of Canada by different chemical methods, which showed that they represented three different classes [2]. Performed studies also showed how the trade of amber changed depending on the discovery of places of amber containing deposits.

Many researchers are interested in the physical and chemical properties of amber [3]. A characteristic feature of such studies is the research into molecular level [4]. Particularly interesting is the content of particles and insects in amber pieces [5]. The paper [6] shows changing landscape of the territories during the work of an enterprise at extraction of amber.

The extraction of amber is developed in those countries where its industrial production is in place [7].

In Rivnensky-Volynsky region of Ukraine significant fields of amber have been found. Extraction work is now underway in Klesivsky field (Sarny District) and in the areas of Volodymyretsky (village of Berezhnytsia) and Dubrovitsky (village of Vilneh). The total reserves are estimated at $100000 \mathrm{t}$, which mostly lie in the sand and sandy clay soils on the depth to $15 \mathrm{~m}$ and are sufficient for research and implementation of new technologies [8].

The discovery of industrial amber placers in Ukraine began from developing Klesivsky deposit in 1980, which is active until now. Further searching and search and estimates within the Klesivsky amber-containing area that have been carried out over the last 30 years, enlarged information about its geological structure and conditions of the formation of initial amber placers.

Productive (Mezhygir) deposits of the south-eastern part of the Klesivsky district (areas of Pugach, Rodnikova, Duny and Fedorivka) fill the lowering between the outputs on the pre-berrics surface of the Proterozoic crystalline formations and their weathering measles (Fig. 1). Productive fields of the Klesivsky deposit are deposited as a strip of the width from 200 to $700 \mathrm{~m}$, which can be traced from the Southeast to the Northwest between the outputs of small pieces of the foundation on the pre-Mezhygir surface. The length of the stripe enriched with amber is over $2 \mathrm{~km}$. The outputs of the crystalline rocks among the Mezhygir sediments are insignificant in size and in the Mezhygir time manifested themselves as numerous abrasion islands with the square about $50 \%$.

Extraction of amber in Ukraine is carried out by mechanical or hydraulic methods, which have a number of shortcominngs. In particular, these are large operational 
and economic costs, removal of mineral soil to the surface, altering the structure of the soils, formation of cavities and a negative environmental impact on the environment.

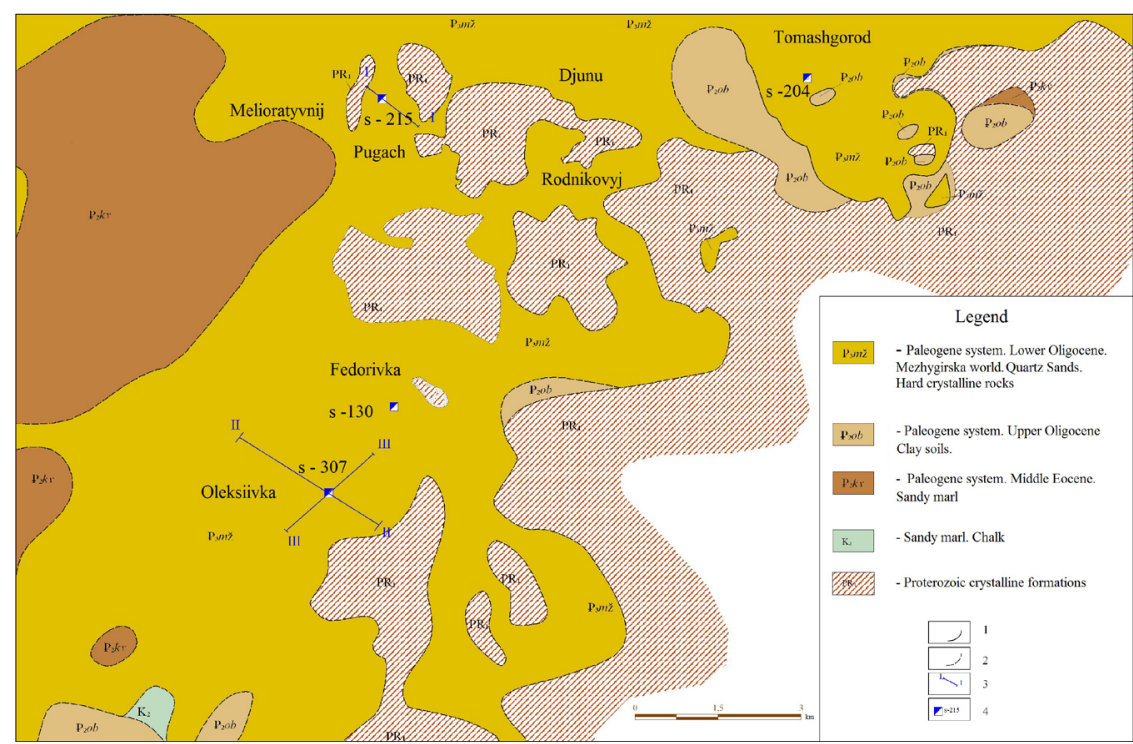

Fig. 1. Schematic geological map of the pre-berrics surface of the southern part of the Klesivsky amber-containing district

Therefore, relevant scientific task at the amber exploration is reducing negative consequences of the application of extracting equipment on natural environment and substantiation of rational parameters of mining equipment to maximum extraction of amber from amber-containing fields.

\section{Analysis of scientific literature and the problem statement}

Extraction of amber from sandy fields are mainly carried out by two methods: mechanical and hydraulic.

At the National University of Water Management and Nature Resources use (NUWMNRU, Rivne, Ukraine) hydromechanical method was proposed for the production of amber, based on saturation of the array with water, excitation mechanically (vibration excitation) and segregation of amber to the surface of the field by Archimedean force. The action and effect on the array by vibrating methods need analysis and study of the processes occurring in the amber-containing sandy soils.

When using this method, vibrating machines act on the soil environment from the top, or are put in the middle of the vibrated mass of soil. Ground mass is a three-phase dispersion system that consists of the solid (the skeleton), the liquid phase (water), which fills the pores, and gaseous (certain volume of air, water steam). The air is in the compressed state, so the bubbles hardly move relative to the skeleton. As for the liquid phase, there are two parts of water: water associated with molecular skeleton and free water, which can move around by the force of gravity and pressure gradient.

As the amber at Klesivsky field lies in sandy soils, then the sandy soil passes into a state of liquefaction at the saturation of water and mechanical action on the environment.

Experimental studies of liquefaction of sandy soils were tackled by many researchers. A research of influence of vibration equipment to the soil environment was carried out by [8].
The studies [2] indicate the features of the ambercontaining fields in Canada and focus on the development of the region at increasing the extraction of amber. Physical-chemical properties of amber allow selecting a method of extraction [3], however, the studies have a scope that is limited by the region of amber extraction. Molecular component has little impact on production, and explores the uniqueness of a valuable sedimentary [4]. The same can be told about the research [5], during which scientists were interested in the presence of the particles and insects in amber. The impact of exploration changes the infrastructure of a region and landscapes of areas [6]. One needs to consider in what way extracting the amber must be carried out for the minimal technogenic and ecological impact on the environment.

Modern technologies and machinery installations can be applied for the production at industrial scale, and where production is not developed, it is necessary to use mobile extraction tools [7].

By the analysis of the scientific literature, one can conclude that the researchers are more interested in the precious value and uniqueness of amber than in the technology. Research into improvement of technologies and technological equipment was tackled by individual scientists [8]. Further research should focus on the implementation of the newest technologies and extraction tools, optimization and intensification of the processes of extraction from amber-containing fields by using hydromechanical method for maximal extraction of amber fromb a deposit.

\section{The purpose and objectives of the study}

The aim is to establish patterns of parameters of interrelation between amber-containing mining mass and vibrohydraulic intensifier for maximal extraction of amber from a deposit.

To achieve the stated goal, the following tasks were formulated:

- to determine the impact of the density of amber-containing environment and vibration of vibrohydraulic intensifier on the separation of amber-containing sands with the purpose of accelerated amber recovery from the depth to the surface;

- to determine the dependencies of the influence of water and air consumption on the intensity of extraction of amber by a vibromechanical intensifier.

\section{Results of experimental research into extraction of amber out of sandy fields}

Main experimental studies were performed in the laboratories of the University, Rivne geological expedition of the enterprise "Ukrpivnitchgeologiya" and the Klesivsky amber-containing sandy field, which is the most character- 
istic of this amber-containing region. The research found that the structure of sandy amber-containing environment is destroyed during liquefaction. Sand particles in the vibration zone, are separated from the total array and driven to vibrational motion at theor equilibrium position and move by certain trajectory relative to the vibration projectile. In this case, there is an intense movement of gas and water that takes along sand particles and amber and throws them to the surface. Since the surface of amber considerably exceeds the square of the particles, then under the influence of Archimedean force the pieces of amber are pushed out to the surface.

At vibration action on a sandy array of soil, the following stages of conversion are observed:

- vibration liquefaction (maximum preparation for intensive mixing);

- vibration boiling (separation of particles and mixing in the array);

- the gradual compacting of an array of sandy soil from the periphery to the source of vibration.

The point of transition from a state of vibration liquefaction to vibration linearization of dry friction is characterized by maximal sealing of the material and maximal resistance of the soil layer.

The effect of vibration liquefaction of the layer is analogous to the phenomenon of vibration linearization of dry friction, i. e. in the presence of vibration, transfer of relative motion to a particle in the environment needs less permanent effort than in its absence. When reducing the effective coefficient of friction in the vibration liquefied state, the particles slide relative to each other without tearing aaway. The layer is compacted while flowing.

It is known from the research [9] that sand displacement in the vibration boiling layer is not subject to the law of motion of the particles in the airless space. In addition to gravity, the environment produces significant influence on the trajectory of the movement of a layer of sand. Liquefaction forms during throwing, while during falling, the pressure increases in the medium. Greater pressure drop is executed on the lower layers of sandy soil than on the top, so the air is displaced from the bottom and the condensation occurs between the particles.

Thus, the vibration boiling layer of sandy soil acts as a pump that is pumping gas-liquid mixture to the surface, capturing the particles and transporting them to the top. In this case the rate of rise of a particle from the bottom to the top depends on the intensity of vibration excitation of the array, liquefaction of the medium, saturation by the air bubbles and the viscosity of the medium.

Pressure drop depends on the frequency and amplitude of the fluctuations, the height of the layer, particle size and moisture content of the sandy soil, and also on the coefficient of friction of particles one by one. The intensity of the pumping action of the vibration boiling layer is characterized by three parameters: pressure over and liquefaction under the vibration boiling layer, the difference of pressure in the layer.

Pumping effect is ensured during vibration in the following sequences: $24-26 \mathrm{~Hz}$; 48-52 Hz; 96-104 Hz.

Hence, the formation of vibration boiling soil layer is affected by the following parameters:

1) amplitude of oscillations;

2) frequency of fluctuations;

3) forcing power;

4) water pressure;

5) air pressure;

6) geometric location of fluctuations exciters.
To a large extent these parameters are determined experimentally.

A significant factor that affects the loosening of the sand mass, is the porosity $\left(\mathrm{n}_{1}\right)$ of the environment, which is determined from the expression:

$$
\mathrm{n}_{1}=\frac{\left(\mathrm{V}_{\mathrm{w}}-\mathrm{V}_{\mathrm{c}}\right)}{\mathrm{V}_{\mathrm{w}}},
$$

where $V_{w}$ is the full volume of the soil layer; $V_{c}$ is the volume of solid particles.

By the results of theoretical and experimental research into behaviour of sands under mechanical action on the change of aggregate state in the environment, minor changes in the array porosity were observed, namely within $\Delta \eta=1-1.5 \%$ [10] (Fig. 2). The liquefaction of environment is estimated by the porosity of vibration boiling layer that depends on the acceleration of vibration. It was found that with insufficient liquefaction the compression of a soil layer occurs, which leads to significant reduction of the amber recovery to the surface. Research into the changes of porosity ( $\varepsilon$ ) of vibration boiling soil layer of the quartz sand under the acceleration of vibration on a laboratory installation allowed obtaining data, based on which a graphical dependency that is presented in Fig. 3 was built.

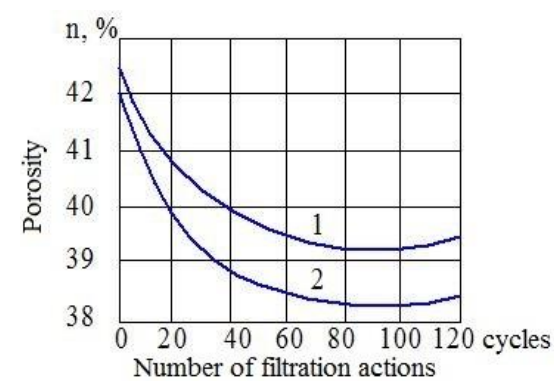

Fig. 2. Dependence of porosity of sandy soil under the influence of an fluctuations exciter: 1 - during the intensity of vibration excitation action for $1 \mathrm{sec} ; 2$ - during the intensity of vibration excitation action for $0.5 \mathrm{sec}$

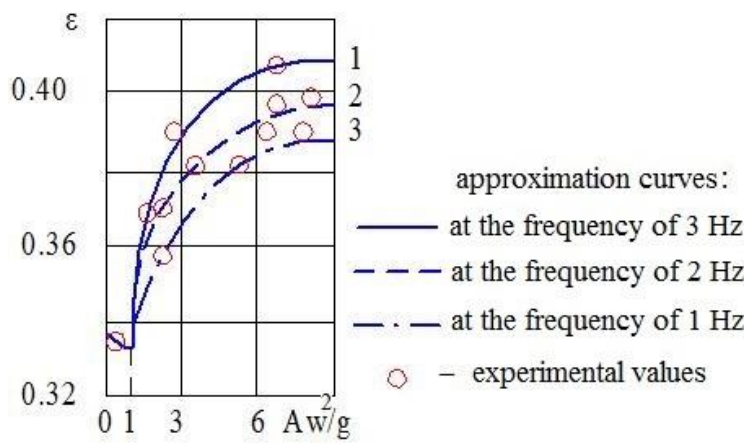

Fig. 3. Dependence of porosity $(\varepsilon)$ of vibration boiling soil layer of the quartz sand on the acceleration of vibrations $\left(\frac{\mathrm{A} \omega^{2}}{\mathrm{~g}}\right)$ at different frequencies $(1-3 \mathrm{~Hz} ; 2-2 \mathrm{~Hz} ; 3-6 \mathrm{~Hz})$

For extraction of amber with the use of hydromechanical method at the National University of Water Management and Environmental Sciences a vibrohydraulic intensifier was designed, which includes a vibrator and guide rods with vibration emitters. The parameters of a vibrohydraulic intensifier were received by the conducted research. 
Experimentally was determined that the amplitude of the oscillations $\left(\mathrm{A}_{\mathrm{K}}\right)$ of a vibration boiling layer has the link between initial porosity of the medium and incremental rise of the the latter at vibration boiling and changes to the value, which is taken into account by the experimental factor $\mathrm{K}$, determined on the basis of processing experiments data by known hydromechanics dependence:

$$
\frac{\Delta \mathrm{h}}{\mathrm{h}_{\text {initial }}}=\mathrm{KA}_{\mathrm{K}},
$$

where $\mathrm{K}$ is the experimental coefficient; $\Delta \mathrm{h}$ is the increase of vibration boiling soil layer from the initial download; $h_{\text {initial }}$ is the initial height of the installation load.

From the research [9], by experiments in laboratory and under the field conditions, it was proved that with increasing distance from the center of the vibration, the amplitude of fluctuations fades while the forces of traction and friction between the particles of amber-containing sand decrease and gradually stop. The more the environment is liquefied, the smaller is the radius of action of vibration projectile. When working with clay and certain loams, the efficiency of vibrators is not expedient.

To receive the data of the effective area of action of the working body of a vibrohydraulic intensifier, additional research was carried out in the laboratory to create a vibration boiling soil layer both in closed installations and in open systems.

This allowed vibrohydraulic intensifier to create a solid suspension environment and remove amber to the surface of the field by segregation in the amber-containing sandy layer.

Experimentally during full-scale research of a vibrohydraulic intensifier, the dependence of the speed of emersion of amber on the vibration parameters and the supply of gas-liquid mixture into the ground array was determined [10].

The maximum liquefaction of colloid mass (density of environment $\left(\rho_{c}\right)$ ) was observed in the sandy soil during the air supply to the boiling soil layer $\mathrm{q}_{\mathrm{a}}=0.02 \mathrm{~m}^{3} / \mathrm{h}$. The density of the colloid mass $\left(\rho_{c}\right)$ was $0.5-0.6 \mathrm{~kg} / \mathrm{m}^{3}$ at the frequency of vibrations of $30 \mathrm{~Hz}$ (Fig. 4).

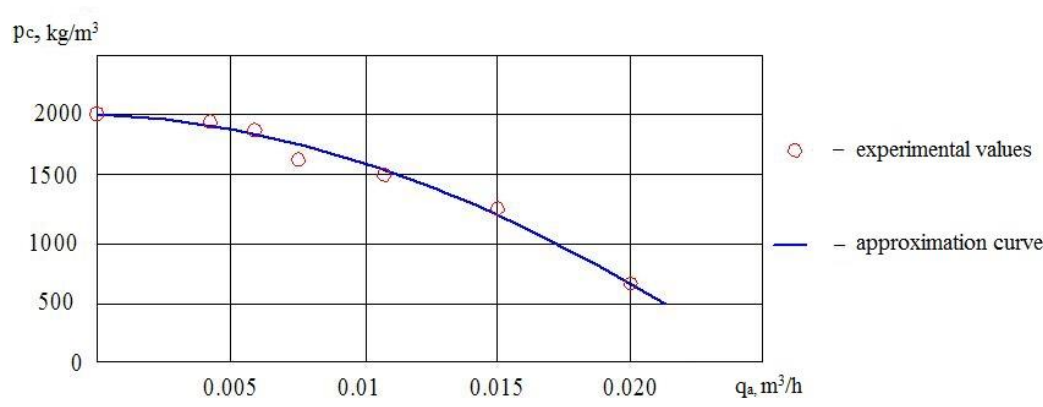

Fig. 4. Dependence of the density of the medium on the air supply $\left(q_{a}\right)$ at the frequency of vibrations of $30 \mathrm{~Hz}$

The minimal medium density $\left(\rho_{\max }\right)$ is $1800 \mathrm{~kg} / \mathrm{m}^{3}$ with the air supply $\left(q_{a}\right) 0.004 \mathrm{~m}^{3} /$ hour was reached at the frequency of vibration of $30-35 \mathrm{~Hz}$.

Air supply within $0.01-0.12 \mathrm{~m}^{3} /$ hour per $1 \mathrm{~m}^{3}$ of sand soil liquefies amber-containing sandy environment and intensifies the process of amber emersion. However, the increased consumption of air leads to a decrease in the speed of emersion. Dependence of the change in density of the medium with the air supply to a boiling soil layer and approximation curve by the results of experimental research are presented in Fig. 5. In this case the volume of extracted amber is $90-95 \%$ of the total reserves in the field.

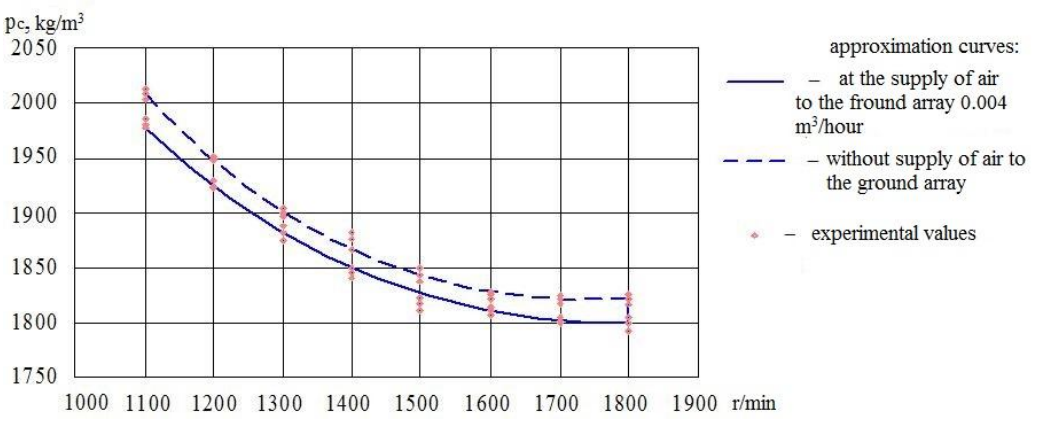

Supply of gas-liquid mixture allows intensifying the process of amber recovery to maximal values, but during formation of air trunks, the boiling process passes into vibration liquefaction and eventually stops. Maximal speed of amber recovery to the surface is observed by changing the supply of gas-liquid mixture to sandy array within 0 to $0.020 \mathrm{~m}^{3}$ /hour.

Segregation in the amber layer and the speed of its recovery are decisive in the working modes of intensifiers.

\section{Discussion of the results of experimental research into extraction of amber out of sandy fields}

The experimental research into extraction of amber out of sandy amber-containing fields found that:

- the speed of amber recovery depends on the frequency of vibration, amplitude and density of the medium and has its extremum;

- there exist optimal values of the water and air supply, at which maximum speed of amber recovery onto the surface of a field is achieved, at different values of frequency of vibration; - the density of the medium significantly influences the formation of conditions for the rapid amber recovery onto the surface, which affects the performance of a vibrohydraulic intensifier of amber;

- there are values for vibration and air and water supply, at which suspension medium is not formed, and the amber recovery onto the surface of the field is absent.

Experimental research established rational density of the medium $\left(\rho_{c}=1600-1800 \mathrm{~kg} / \mathrm{m}^{3}\right)$, which is achieved by the frequency of vibrations of $30-35 \mathrm{~Hz}$, amplitude $\mathrm{A}=1.07-2.5 \mathrm{~mm}$, air supply $\mathrm{q}_{\mathrm{a}}=0.004-0.006 \mathrm{~m}^{3} /$ hour, at which the speed of amber recovery $\mathrm{v}=0.1-0.15 \mathrm{~m} / \mathrm{s}$. Consolidated data on experimental research on determining rational parameters of a vibrohydraulic intensifier are presented as approximating dependencies in Fig. 6.

Intensification of the process of amber extraction is possible by applying vibration, supply of water to the ground array, or water and air.

Consumption of water is determined from the next dependency [10]:

$$
Q_{\mathrm{ew}}=\frac{\mathrm{AB} \vartheta}{1+\mathrm{e}}\left(\frac{\left(\rho_{\mathrm{sk}}(1+\mathrm{W})-\rho_{\mathrm{e}}(1+\mathrm{e})\right)}{\rho_{\mathrm{e}}-\rho_{\mathrm{w}}}\right) .
$$




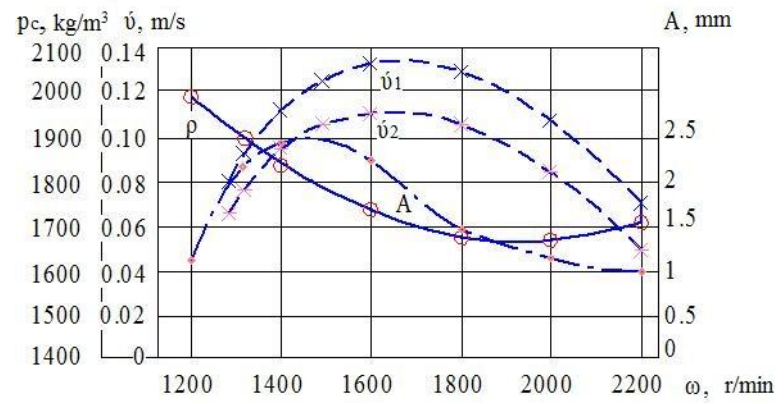

Fig. 6. Dependence of the density $(\rho)$, speed of amber recovery $\left(v_{1}\right.$ at $q_{a}=0.004 \mathrm{~m}^{3} /$ hour, $v_{2}$ at $q_{a}=0.006 \mathrm{~m}^{3} /$ hour $)$, amplitude of intensifier $(A)$ on the frequency of vibration during experimental studies

During the supply of air into an array, the process intensifies and the air consumption is determined by the following dependency:

$$
Q_{\text {sur }}=\frac{n_{1} A B \vartheta\left(\rho_{w}-\rho_{e}\right)+\frac{A B \vartheta}{1+e}\left(\rho_{\text {sk }}(1+W)-\rho_{e}(1+e)\right)}{\rho_{e}},
$$

where $v$ is the speed of the installation, $\mathrm{m} / \mathrm{h}$; e is the coefficient of porosity; $\mathrm{W}$ is the soil humidity; $\rho_{\text {ск }}$ is the soil skeleton density, $\mathrm{kg} / \mathrm{m}^{3} ; \rho_{\mathrm{B}}$ is the water density, $\mathrm{kg} / \mathrm{m}^{3} ; \rho_{\mathrm{p}}$ is the density of medium, $\mathrm{kg} / \mathrm{m}^{3} ; \rho_{\mathrm{p}}$ is the density of the air; $\mathrm{n}_{1}$ is the porosity in a natural state; $\mathrm{A}, \mathrm{B}$ are the width, the length of an array of soil, which vary, $\mathrm{m}$.

Additional research conducted in clay soils indicate that the speed of amber recovery is affected by the size of fragments of amber (speed increases with the increase in dimensions) and optimal density of the medium.

The optimal density of the medium, at which the speed of amber recovery $\mathrm{v}=0.5-0.6 \mathrm{~m} / \mathrm{s}$ is achieved, is $\rho_{\mathrm{c}}=1450-1500 \mathrm{~kg} / \mathrm{m}^{3}$.

Determining the capacity of vibration installations is mostly performed by the dependency

$$
\mathrm{N}=\mathrm{P} \cdot \bar{\varpi} \cdot \mathrm{A}_{\mathrm{K}} \cdot \sin \delta
$$

where $\mathrm{P}=\mathrm{MA}_{\mathrm{K}} \bar{\varpi}^{2}$ is the maximum exciting power; $\varpi$ is the frequency of vibration; $\mathrm{M}=\mathrm{mgA}_{\mathrm{K}}$ is the kinetic momentum; $\mathrm{m}$ is the weight of the equipment; $\mathrm{g}$ is the acceleration of gravity; $\mathrm{A}_{\mathrm{K}}$ is the amplitude of oscillations; $\delta=20^{\circ}$ is the phase angle.

\section{Conclusions}

As a result of the studies we found that:

- application of hydromechanical method of extraction of amber with the help of the studied vibrohydraulic intensifier allows extracting $90-95 \%$ of the amber from a deposit, in this case the medium density and vibration influence the liquefaction of amber-containing sand, namely, the optimal density $\left(\rho_{\mathrm{c}}\right)$ is $1600-1800 \mathrm{~kg} / \mathrm{m}^{3}$, the frequency of vibrations of $30-35 \mathrm{~Hz}$, amplitude $\mathrm{A}=1.07-2.5 \mathrm{~mm}$;

- maximal speed of amber recovery to the surface is achieved depending on the changes in the consumption of water and air by a vibrohydraulic intensifier for specific amber-containing fields and the optimal values were obtained during performed laboratory and field experimental research.

\section{References}

1. Van der Werf, I. D. The molecular composition of Sicilian amber [Text] / I. D. Van der Werf, D. Fico, G. E. De Benedetto, L. Sabbatini // Microchemical Journal. - 2016. - Vol. 125. - P. 85-96. doi: 10.1016/j.microc.2015.11.012

2. Poulin, J. The characterisation of amber from deposit sites in western and northern Canada [Text] / J. Poulin, K. Helwig // Journal of Archaeological Science: Reports. - 2016. - Vol. 7. - P. 155-168. doi: 10.1016/j.jasrep.2016.03.037

3. Seyfullah, L. Species-level determination of closely related araucarian resins using FTIR spectroscopy and its implications for the provenance of New Zealand amber [Text] / L. Seyfullah, E. Sadowski, A. Schmidt // PeerJ. - 2015. - Vol. 3. - P. e1067. doi: 10.7717/ peerj.1067

4. Havelcova, M. Vibrational spectroscopy with chromatographic methods in molecular analyses of Moravia number samples (Czech Republic) [Text] / M. Havelcova, V. Machovic, M. Linhartova, L. Lapcak, A. Prichystal, Z. Dvorak // Microchemical Journal. 2016. - Vol. 128. - P. 153-160. doi: 10.1016/j.microc.2016.04.010

5. Alekseev, V. The beetles (Insecta: Coleoptera) of Baltic amber: the check list of described species and preliminary analysis of biodiversity [Text] / V. Alekseev // Zoology and Ecology. - 2013. - Vol. 23, Issue 1. - P. 5-12. doi: 10.1080/21658005.2013.769717

6. Burnashov, E. Natural evolution of western shore of the Sambian Peninsula on completion of dumping from an amber mining plant [Text] / E. Burnashov, B, Chubarenko, Z. Stont // Archives of Hydro-Engineering and Environmental Mechanics. - 2010. - Vol. 2, Issue 57. - P. 105-117.

7. Radwanek-Bak, B. Valorization of undeveloped industrial rock deposits in Poland [Text] / B. Radwanek-Bak, M. Niec // Resources Policy. - 2015. - Vol. 45. - P. 290-298. doi: 10.1016/j.resourpol.2015.07.001

8. Malanchyk, Z. Modern condition and problems of extraction of amber in Ukraine [Text] / Z. Malanchyk, V. Korniyenko // Canadian Journal of Science and Education. - 2014. - Vol. 2, Issue 6. - P. 372-376.

9. Bulat, A. Substantiations of technological parameters of extraction of amber in Ukraine [Text] / A. Bulat, V. Naduty, V. Korniyenko // American Journal of Scientific and Educational Research. - 2014. - Vol. 2, Issue 5. - P. 591-597

10. Romanovskuj, O. L. Doslidgennja vytrat vody i povitrja shtangovogo vibrogidravlichnogo vutjagacha [Text] / O. L. Romanovskuj, V. Ya. Korniyenko // Visnyk NYVGP. - 2009. - Vol. 2, Issue 46, Part 1. - P. 330-336. 